\title{
Leaf photosynthetic characteristics and photosystem II photochemistry of rice (Oryza sativa L.) under potassium-solubilizing bacteria inoculation
}

\author{
M. YAGHOUBI KHANGHAHI*, H. PIRDASHTI*, H. RAHIMIAN**, G.H. NEMATZADEH ${ }^{* * *}$, \\ M. GHAJAR SEPANLOU ${ }^{\#}$, E. SALVATORI ${ }^{\#}$, and C. CRECCHIO ${ }^{\# \#,+}$
}

\begin{abstract}
Department of Agronomy, Genetics and Agricultural Biotechnology Institute of Tabarestan and Sari Agricultural Sciences and Natural Resources University, 9th km of Farah Abad Road, 4818168984, Sari, Māzandarān, Iran* Department of Plant Pathology, Sari Agricultural Sciences and Natural Resources University, 9th km of Farah Abad Road, 4818168984, Sari, Māzandarān, Iran ${ }^{* *}$

Department of Plant Breeding, Genetics and Agricultural Biotechnology Institute of Tabarestan and Sari Agricultural Sciences and Natural Resources University, 9th km of Farah Abad Road, 4818168984, Sari, Māzandarān, Iran ${ }^{* * *}$

Department of Soil Sciences, Sari Agricultural Sciences and Natural Resources University, 9th km of Farah Abad Road, 4818168984, Sari, Māzandarān, Iran

Department of Environmental Biology, Sapienza University of Rome, Piazzale Aldo Moro 5, 00185 Rome, Italy Department of Soil, Plant and Food Sciences, University of Bari Aldo Moro, Via Amendola 165/a, 70125 Bari, Italy ${ }^{\# \#}$
\end{abstract}

\begin{abstract}
The current research was performed to investigate the effects of three potassium-solubilizing bacteria (KSB) strains (Pantoea agglomerans, Rahnella aquatilis, and Pseudomonas orientalis) on leaf photosynthetic characteristics in rice (Oryza sativa L. cv. Pajohesh). A pot and a field experiment were conducted in a paddy field. The results indicated that the KSB inoculums significantly enhanced chlorophyll (Chl) $a$, Chl $a+b$, SPAD value, and stomatal conductance as compared to the control in both experiments, especially when applied along with half the recommended dose of the potassium chemical fertilizer. KSB inoculations, alone or combined with K fertilizer, significantly increased the value of photochemical quenching, photosynthetic electron transport rate, and the effective quantum efficiency as compared to the control. In conclusion, these native KSB strains could be used as inoculants to reduce consumption of K chemical fertilizer and improve the efficiency of photosynthesis for rice production under the flooding irrigation conditions.
\end{abstract}

Additional key words: chlorophyll florescence; grain yield; photosynthetic pigments; potassium uptake; potassium utilization.

\section{Introduction}

Rice (Oryza sativa L.) is one of the principal food crops worldwide. Globally, around 163 million hectares of rice paddy field were cultivated in 2016. Asia accounts for $90 \%$ of global rice production and consumption and a paddy production of nearly 678 million tones (FAO 2016). Iran is also an important area for rice cultivation with a total rice production of 2.9 million tones, about $40 \%$ of it is produced in Mazandaran province in northern Iran (FAO 2016, Yaghoubi Khanghahi et al. 2018a).

Rice growth and productivity depends considerably on several factors, especially soil fertility and soil nutrient contents (Yaghoubi Khanghahi et al. 2018b). Potassium (K) is an essential nutrient to improve rice growth and grain yield (Carmeis Filho et al. 2017). K also plays key roles to maintain stronger photosynthetic ability with high resistance to photoinhibition and to keep PSII reaction center

\footnotetext{
Received 29 August 2018, accepted 14 December 2018.

${ }^{+}$Corresponding author; e-mail: carmine.crecchio@uniba.it

Abbreviations: Chl - chlorophyll; ChlF - chlorophyll fluorescence; DAT - days after transplanting; ETR - electron transport rate; $\mathrm{F}$ - steady-state fluorescence; $\mathrm{F}_{0}$ - minimal fluorescence yield of the dark-adapted state; $\mathrm{F}_{0}{ }^{\prime}$ - minimal fluorescence yield of the light-adapted state; $F_{m}$ - maximal fluorescence yield of the dark-adapted state; $F_{m}{ }^{\prime}$ - maximal fluorescence yield of the light-adapted state; $F_{v}$ - variable fluorescence; $F_{v} / F_{m}$ - maximal quantum yield of PSII photochemistry; KSB - potassium solubilizing bacteria; $\mathrm{NPQ}$ - nonphotochemical quenching; $\mathrm{q}_{\mathrm{L}}$ - coefficient of photochemical fluorescence quenching assuming that all reaction centers share a common light-harvesting antenna; $\mathrm{q}_{\mathrm{N}}$ - nonphotochemical quenching coefficient; $\mathrm{q}_{\mathrm{P}}$ - photochemical quenching coefficient; $\mathrm{Y}_{(\mathrm{NO})}-$ quantum yield of regulated energy dissipation; $\mathrm{Y}_{(\mathrm{NPQ})}-$ quantum yield of light-induced nonphotochemical quenching; $\Phi_{\mathrm{PSII}}-$ effective quantum yield of PSII photochemistry.

Acknowledgments: The authors thank the Genetics and Agricultural Biotechnology Institute of Tabarestan (GABIT) and Sari Agricultural Sciences and Natural Resources University (SANRU), Sari, Iran, for providing financial support for this study. We also thank Dr. Yasser Yaghoubian for scientific revisions.
} 
less damaged and a significantly higher net stomatal conductance in rice (Jia et al. 2008). Rice absorbs large quantities of $\mathrm{K}$ which is greater than any other essential nutrients, such as nitrogen $(\mathrm{N})$ and phosphorus $(\mathrm{P})$ (Krishna 2014). Average nutrient acquisition and accumulation by rice is around $22.2 \mathrm{~kg} \mathrm{~N}, 3.1 \mathrm{~kg} \mathrm{P}$, and $26.6 \mathrm{~kg} \mathrm{~K}$ per ton of grain yield (Krishna 2014).

$\mathrm{K}$ deficiency disrupts the leaf photosynthetic function and results in lower rates of net photosynthesis, stomatal conductance, Rubisco activity, and especially declines the grain yield in rice (Zhao et al. 2016). Evaluations of chlorophyll (Chl) fluorescence (ChlF) are used as a powerful tool for nondestructive testing of photosynthetic energy conversion efficiency in crops (Salvatori et al. 2014, Yaghoubian et al. 2016). This technique has been widely used to study the response of crops to environmental stimuli, such as effects of low $\mathrm{K}$ on the photosynthetic apparatus of crops both in a controlled environment and in the field (Zhao et al. 2016).

Nowadays, farmers usually use injudicious application of chemical fertilizers to overcome deficiency of nutrients and reach maximum agricultural productivity (de Souza et al. 2015). The global average of total consumption of $\mathrm{N}$, $\mathrm{P}$, and $\mathrm{K}$ fertilizers is $107 \mathrm{~kg} \mathrm{ha}^{-1}$ (Meena et al. 2017) and their use efficiency is approximately $30-60 \%$ for N, less than $20 \%$ for $\mathrm{P}$, and $30-50 \%$ for K (Fageria et al. 2014). However, negligible application of K chemical fertilizer has been recorded due to lack of awareness of its importance in crop production and its high price as compared to other chemical fertilizers (Zhao et al. 2016, Meena et al. 2017). On the other hand, imbalanced or overdose use of chemical fertilizers has the adverse impacts on soil and water quality and food safety (Bakhshandeh et al. 2015). Therefore, interest has grown in ecofriendly and costeffective agrotechnologies to enhance crop production and reduce the chemical fertilizers input while minimizing negative effects on the environment and food (Pii et al. 2016, Yaghoubi Khanghahi et al. 2018a). For this purpose, the utilization of plant growth-promoting rhizobacteria (PGPR) could be considered as a sound strategy in rice cultivation systems (Yaghoubi Khanghahi et al. 2018a). These beneficial bacteria, such as K-solubilizing bacteria (KSB) play an important role in nutrient solubilization, mobilization, mineralization, dissolving, and uptake of nutrients (Meena et al. 2017, Nath et al. 2017). The KSBs are able to convert the insoluble or mineral structural $\mathrm{K}$ compounds into an available form of $\mathrm{K}$ in soils (Nath et al. 2017). Direct and indirect mechanisms of PGPR are biological nitrogen fixation, organic matter mineralization, phytohormone productions, e.g., auxins, cytokinins, and gibberellins; biological control against soil-borne pathogens, cellulose degradation, starch hydrolysis, production of hydrogen cyanide, antibiotic, siderophore, and certain volatile organic compounds (Pii et al. 2015, Meena et al. 2017). The majority of credible group of PGPR belongs to genera Acinetobacter, Azadirachta, Azotobacter, Azospirillium, Bacillus, Burkholderia, Pantoea, Pseudomonas, Rahnella, Rhizobium, Serratia, and Streptomyces sp. (Bakhshandeh et al. 2014, Scagliola et al. 2016, Yaghoubi Khanghahi et al. 2018c).
Research has focused on soil-plant-microbe interaction in recent decades (Meena et al. 2017). So far numerous bacterial species, mostly associated with the crop rhizosphere, have been tested and found to be beneficial for plant growth, yield, and crop quality, but there is no information about the effect of KSB inoculations (alone or combined with $\mathrm{K}$ chemical fertilizer) on photosynthetic pigments and $\mathrm{ChF}$ parameters. Therefore, the major objective of the present study was to investigate the effects of three native KSB strains proposed by Yaghoubi Khanghahi et al. (2018b), Pantoea agglomerans, Rahnella aquatilis, and Pseudomonas orientalis, on leaf photosynthetic pig-ments, stomatal conductance, and ChlF parameters in rice plant. Our hypothesis is that the inoculation by native KSB strains is able to enhance significantly the photosynthetic performance of rice plants by raising the efficiency of $\mathrm{K}$ utilization, thus improving crop yield and concurrently reducing consumption of $\mathrm{K}$ chemical fertilizer.

\section{Materials and methods}

Three KSB strains of $P$. agglomerans $(P a), R$. aquatilis $(R a)$, and $P$. orientalis $(P o)$ were isolated from the paddy rhizosphere soil across Mazandaran province in northern Iran. The soil characteristics, isolation of KSB, their potassium solubilizing ability, and identification methods are fully described in Yaghoubi Khanghahi et al. (2018b). The current supplementary research was performed to measure their capabilities on photosynthetic performance and crop yield of rice plants. The levels of potassium fertilizer, commercial biofertilizer and KSBs inoculation applied in pot and field experiments are listed in the text table further (+: inocu-lation with $\mathrm{KSBs},-$ : inoculation without $\mathrm{KSBs}$ ).

The field experiment was conducted in a paddy field of Mazandaran province (Sari, located at $36^{\circ} 3^{\prime} \mathrm{N}, 53^{\circ} 04^{\prime} \mathrm{E}$, altitude of $11 \mathrm{~m}$ below the average of sea level, with longterm annual precipitation mean of $780.7 \mathrm{~mm}$ and long-term annual temperature mean of $18.1^{\circ} \mathrm{C}$ ) with Mediterranean climate conditions (according to Domarten classification), in a randomized complete block design (RCBD) with three replications. Nine square meter plots $(3 \times 3 \mathrm{~m})$ were arranged and 25-d-old seedlings (about 20-25 cm in height) were transplanted in the plots at a spacing of $20 \times$ $20 \mathrm{~cm}$. In order to prevent water penetration through plots, a fixed distance of $100 \mathrm{~cm}$ was determined among plots. The chemical and physical properties of the soil (at a depth of $0-30 \mathrm{~cm}$ ) are presented in Table 1S (supplement).

Pot experiment was performed in a completely randomized design (CRD), in pots filled with $6 \mathrm{~kg}$ of sterile soil. Rice seedlings (135) were used in the pot experiment (15 treatments $\times 3$ replications $\times 3$ seedlings per pot), and the total duration of the experiment was $121 \mathrm{~d}$. Experimental soil was collected from rice growing area, where field experiment was conducted, and sterilized using an autoclave (high pressure at $103421 \mathrm{~Pa}, 121^{\circ} \mathrm{C}$ for $60 \mathrm{~min}$, twice before use). The pots were kept outside and therefore the growing conditions were similar to the field experiment. 


\begin{tabular}{|c|c|c|c|c|c|c|}
\hline $\begin{array}{l}\text { Commercial K } \\
\text { biofertilizer (CB) }\end{array}$ & $\begin{array}{l}\text { Pseudomonas } \\
\text { orientalis }(\mathrm{Po})\end{array}$ & $\begin{array}{l}\text { Rahnella } \\
\text { aquatilis }(R a)\end{array}$ & $\begin{array}{l}\text { Pantoea } \\
\text { agglomerans }(\mathrm{Pa})\end{array}$ & $\begin{array}{l}\text { K chemical } \\
\text { fertilizer }\end{array}$ & $\begin{array}{l}\text { NP chemical } \\
\text { fertilizers }\end{array}$ & Abbreviation \\
\hline- & - & - & - & - & - & Control (-NPK) \\
\hline- & - & - & - & - & $100 \% \mathrm{~N}, 100 \% \mathrm{P}$ & $\mathrm{NP}$ \\
\hline- & - & - & - & $50 \%$ & $100 \% \mathrm{~N}, 100 \% \mathrm{P}$ & $\mathrm{NP}^{1} / 2 \mathrm{~K}$ \\
\hline- & - & - & - & $100 \%$ & $100 \% \mathrm{~N}, 100 \% \mathrm{P}$ & NPK \\
\hline- & - & - & + & - & $100 \% \mathrm{~N}, 100 \% \mathrm{P}$ & $\mathrm{NP}+\mathrm{Pa}$ \\
\hline- & - & + & - & - & $100 \% \mathrm{~N}, 100 \% \mathrm{P}$ & $\mathrm{NP}+R a$ \\
\hline- & + & - & - & - & $100 \% \mathrm{~N}, 100 \% \mathrm{P}$ & $\mathrm{NP}+P o$ \\
\hline+ & - & - & - & - & $100 \% \mathrm{~N}, 100 \% \mathrm{P}$ & $\mathrm{NP}+\mathrm{CB}$ \\
\hline- & - & - & + & $50 \%$ & $100 \% \mathrm{~N}, 100 \% \mathrm{P}$ & $\mathrm{NP}^{1} / 2 \mathrm{~K}+P a$ \\
\hline- & - & + & - & $50 \%$ & $100 \% \mathrm{~N}, 100 \% \mathrm{P}$ & $\mathrm{NP}^{1} / 2 \mathrm{~K}+R a$ \\
\hline- & + & - & - & $50 \%$ & $100 \% \mathrm{~N}, 100 \% \mathrm{P}$ & $\mathrm{NP}^{1} / 2 \mathrm{~K}+P o$ \\
\hline+ & - & - & - & $50 \%$ & $100 \% \mathrm{~N}, 100 \% \mathrm{P}$ & $\mathrm{NP}^{1} / 2 \mathrm{~K}+\mathrm{CB}$ \\
\hline- & - & + & + & $50 \%$ & $100 \% \mathrm{~N}, 100 \% \mathrm{P}$ & $\mathrm{NP}^{1} / 2 \mathrm{~K}+P a+R a$ \\
\hline- & + & - & + & $50 \%$ & $100 \% \mathrm{~N}, 100 \% \mathrm{P}$ & $\mathrm{NP}^{1} / 2 \mathrm{~K}+P a+P o$ \\
\hline- & + & + & - & $50 \%$ & $100 \% \mathrm{~N}, 100 \% \mathrm{P}$ & $\mathrm{NP}^{1} / 2 \mathrm{~K}+R a+P o$ \\
\hline
\end{tabular}

Inoculants: The three KSB strains were grown in nutrient broth medium (NB, Merck, Germany; $8 \mathrm{~g} \mathrm{l}^{-1}$ ) by ino-

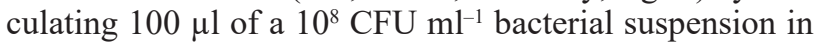
21 of NB medium under agitation at $100 \times g$ on an orbital shaker (Model 3031; GFL, Germany) for $48 \mathrm{~h}$ at $30^{\circ} \mathrm{C}$ to a final density of $10^{7} \mathrm{CFU} \mathrm{ml}^{-1}$. Rice seedlings (cv. Pajohesh, an improved cultivar) were inoculated with each bacterial suspension at room temperature $\left(25^{\circ} \mathrm{C}\right)$ for $5 \mathrm{~h}$ (Bakhshandeh et al. 2017). Control rice seedlings were also treated in the same way with noninoculated NB medium before transplanting in the field and pot. In addition, a com mercial K biofertilizer (formulated by Zist Fanavar Sabz Company, Iran) including two isolates of Pseudomonas koreensis and $P$. vancouverensis was tested to compare with the native KS bacteria.

Chemical fertilization: Based on the results of the soil test, urea $(46 \% \mathrm{~N})$ was used as $\mathrm{N}$ fertilizer equivalent to $160 \mathrm{~kg} \mathrm{ha}^{-1}$. $\mathrm{P}$ and $\mathrm{K}$ chemical fertilizers were added through triple superphosphate $\left(46 \% \mathrm{P}_{2} \mathrm{O}_{5}\right)$ and potassium sulphate $\left(44 \% \mathrm{~K}_{2} \mathrm{O}\right)$ equivalent to 120 and $95 \mathrm{~kg} \mathrm{ha}^{-1}$, respectively, as basal fertilizer before transplanting. Two thirds of the urea fertilizer application were also added during a land preparation before planting, while the rest was applied $30 \mathrm{~d}$ after transplanting. A water depth of $3 \mathrm{~cm}$ was kept to all pots and plots from transplanting time until two weeks before harvest maturity.

Chlorophyll content: The relative Chl content (SPAD value), and Chl $a, \mathrm{Chl} b$, and carotenoids (Car) contents were measured by a portable Chl meter (SPAD-502, Minolta, Japan), and by the method described by Porra (2002), respectively. Three rice seedlings were selected for mea-suring from each plot and pot $(3$ rice seedlings $\times 45$ plots/pots $=135$ rice seedlings). The youngest expanded leaves of each treatment were selected as the materials $(n=9$ leaves). Measurements were made at the anthesis stage (62 d after transplanting, 62 DAT), from 10-13 h. The leaves surface temperature was around $27^{\circ} \mathrm{C}$.
For Chl $a$, Chl $b$, and Car determinations, fresh samples of leaves $\left(1.0 \mathrm{~cm}^{2}\right)$ were extracted by incubation in methanol at room temperature for $24 \mathrm{~h}$ in darkness and determined at the visible wavelengths of $665.2\left(\mathrm{~A}_{665.2}\right)$, $652.4\left(\mathrm{~A}_{652.4}\right)$, and $470\left(\mathrm{~A}_{470}\right) \mathrm{nm}$ using a spectrophotometer (SPEKOL 1300, Analytic, Jena, Germany) (Yaghoubian et al. 2016). The contents of Chl $a, \mathrm{Chl} b$, and Car were calculated by the following equations:

Chl $a\left[\mu \mathrm{g} \mathrm{ml}^{-1}\right]=162.72 \mathrm{~A}_{665.2}-9.16 \mathrm{~A}_{652.4}$

$\mathrm{Chl} b\left[\mu \mathrm{g} \mathrm{ml}^{-1}\right]=34.09 \mathrm{~A}_{652.4}-15.28 \mathrm{~A}_{665.2}$

$\operatorname{Car}\left[\mu \mathrm{g} \mathrm{ml}^{-1}\right]=\left(1,000 \mathrm{~A}_{470}-1.8 \mathrm{Chl} a-85.02 \mathrm{Chl} b\right) / 198$

Chl fluorescence (ChIF) and stomatal conductance $\left(g_{s}\right)$ were measured with the same leaves and times as for SPAD measurements. ChlF was measured by using a pulse amplitude modulated fluorometer (PAM-2500, Walz, Germany), as described by Genty et al. (1989). The samples were acclimated to dark for $30 \mathrm{~min}$ before the mea-surements. The leaf was then exposed to low intensity light $\left[<0.1 \mu \mathrm{mol}(\right.$ photon $) \mathrm{m}^{-2} \mathrm{~s}^{-1}$, red light $]$. Afterwards, a saturating light pulse $\left[>8,000 \mu \mathrm{mol}\right.$ (photon) $\mathrm{m}^{-2} \mathrm{~s}^{-1}$, white light) was turned on for $1 \mathrm{~s}$ (one pulse). The maximum quantum yield of PSII was evaluated on dark-adapted leaves as $F_{\mathrm{v}} / \mathrm{F}_{\mathrm{m}}=\left[\left(\mathrm{F}_{\mathrm{m}}-\mathrm{F}_{0}\right) / \mathrm{F}_{\mathrm{m}}\right]$ where $\mathrm{F}_{0}$ is the basal fluorescence, $F_{v}$ the variable fluorescence, and $F_{m}$ is the maximum fluorescence. The effective quantum efficiency $\Phi_{\text {PSII }}$ was evaluated as $\left(\mathrm{F}_{\mathrm{m}}{ }^{\prime}-\mathrm{F}\right) / \mathrm{F}_{\mathrm{m}}{ }^{\prime}$, where $\mathrm{F}$ is the steadystate fluorescence and $\mathrm{F}_{\mathrm{m}}{ }^{\prime}$ is the maximum fluorescence measured in light-exposed leaf samples. The photosynthetic electron transport rate [ETR, $\mu$ mol(electron) $\mathrm{m}^{-2} \mathrm{~s}^{-1}$, the quantum yield of light induced nonphotochemical quenching $\left[\mathrm{Y}_{(\mathrm{NPQ})}=\left(\mathrm{F} / \mathrm{F}_{\mathrm{m}}{ }^{\prime}\right)-\left(\mathrm{F} / \mathrm{F}_{\mathrm{m}}\right)\right]$, the quantum yield of nonregulated energy dissipation $\left[\mathrm{Y}_{(\mathrm{NO})}=\mathrm{F} / \mathrm{F}_{\mathrm{m}}\right]$, the nonphotochemical quenching $\left[\mathrm{NPQ}=\left(\mathrm{F}_{\mathrm{m}} / \mathrm{F}_{\mathrm{m}}{ }^{\prime}\right)-1\right]$, coefficient of nonphotochemical fluorescence quenching $\left(\mathrm{q}_{\mathrm{N}}\right)$, coefficient of photochemical fluorescence quenching based on a model of separate photosynthetic units $\left(\mathrm{q}_{\mathrm{P}}\right)$, 
and coefficient of photochemical fluorescence quenching assuming that all reaction centers share a common lightharvesting antenna $\left(\mathrm{q}_{\mathrm{L}}\right)$ (Bilger and Björkman 1990), were also calculated. A portable porometer (KR1301, Korea Tech, Korea) was used to determine the stomatal conductance $\left[g_{\mathrm{s}}, \mathrm{mmol}\left(\mathrm{H}_{2} \mathrm{O}\right) \mathrm{m}^{-2} \mathrm{~s}^{-1}\right]$.

Grain yield and $K$ concentration: Grain yield was measured by removing $1 \mathrm{~m}^{2}$ of rice plants from each plot ( 25 plants in each treatment) and two rice plants from each pot at harvest time (94 DAT). The grain was oven-dried at $70^{\circ} \mathrm{C}$ and dry mass was recorded after $72 \mathrm{~h}$. Moreover, rice straw was dried and was used to determine $\mathrm{K}$ concentration at the anthesis stage (62 DAT) by flame photometer (PFP7, Jenway, UK).

Statistical analysis: Analysis of variance ( $A N O V A)$ and the least significant difference (LSD) test were performed using the MSTAT-C software (version 1.42, Michigan State University, USA) to compare the differences between treatments means at a 0.05 level. The correlation (Pearson, 2 tailed) and regression (multiple linear regression, enter method) analyses were done using SPSS software (Statistical Product and Service Solutions, version 16, IBM, New York, USA).

\section{Results}

Grain yield and $\mathrm{K}$ accumulation in straw: The maximum rice grain yield was recorded in the NPK $\left(632.3 \mathrm{~g} \mathrm{~m}^{-2}\right)$ and $\mathrm{NP}^{1} / 2 \mathrm{~K}+R a+P o\left(659.1 \mathrm{~g} \mathrm{~m}^{-2}\right)$ treatments in the pot and field experiments, respectively. While the lowest yield was found in the control treatment $(-\mathrm{NPK})$ treatment of both experiments (447.7 and $431.2 \mathrm{~g} \mathrm{~m}^{-2}$, respectively), single KSB inoculations (without $\mathrm{K}$ chemical fertilizer) insignificantly increased the grain yield as compared to the NP treatment in the pot experiment. By contrast, this difference was significant in the field experiment. In addition, these findings showed that the inoculation with $R$. aquatilis had more positive effects on grain yield than other strains, especially, by applying half the recommended dose of $\mathrm{K}$ chemical fertilizer (Fig. 1A,C). Based on the pot experiment results, the maximum value of $\mathrm{K}$ accumulation in straw was observed in $\mathrm{NP}^{1} / 2 \mathrm{~K}+\mathrm{Pa}+\mathrm{Ra}$, NPK, and $\mathrm{NP}^{1} / 2 \mathrm{~K}+R a$ treatments equal to $10.81,10.73$, and $10.71 \mathrm{~g} \mathrm{~m}^{-2}$, respectively (Fig. 1). The straw K content in the field experiment was also highly influenced by $\mathrm{K}$ fertilizer application alone or combined with KSB inoculations. $\mathrm{K}$ uptake by straw was significantly influenced by $\mathrm{NP}^{1} / 2 \mathrm{~K}+P a+R a$ treatment which were about $2.5,2.2$, and 1.5 times of those in $-\mathrm{NPK}, \mathrm{NP}$, and $\mathrm{NP}^{1} / 2 \mathrm{~K}$ treatments, respectively (Fig. $1 B, D)$.

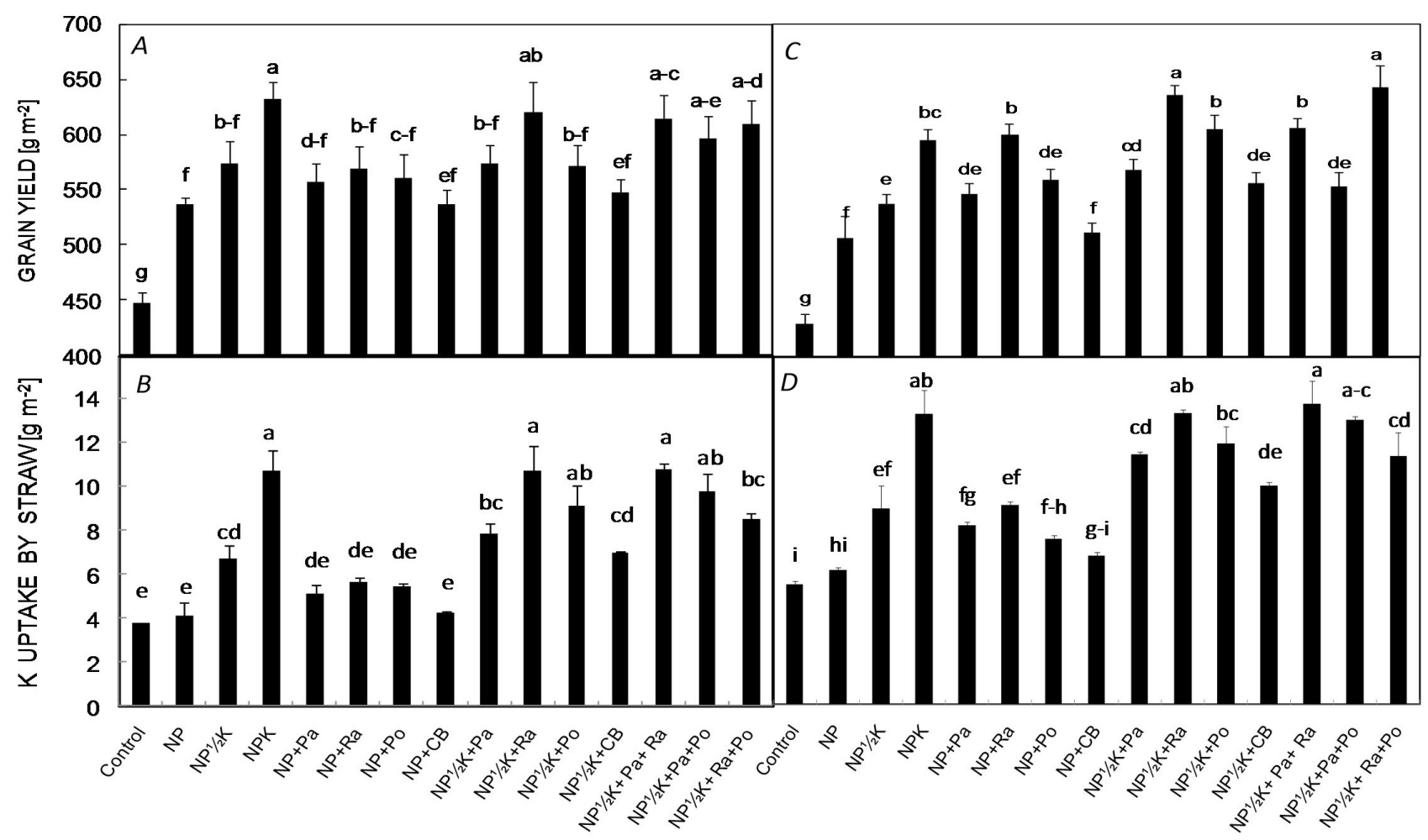

DIFFERENT LEVELS OF POTASSIUM FERTILIZER AND BACTERIA INOCULATION

Fig. 1. The response of grain yield $(A, C)$ and $\mathrm{K}$ concentration in straw $(B, D)$ to potassium solubilizing bacteria (KSB) inoculations and $\mathrm{K}$ chemical fertilizer application in pot (left panel) and field (right panel) experiments. Means in each trait and each experiment followed by the same letter( $s$ ) are not significantly different based on the least significant difference (LSD) test at 0.05 probability level. 


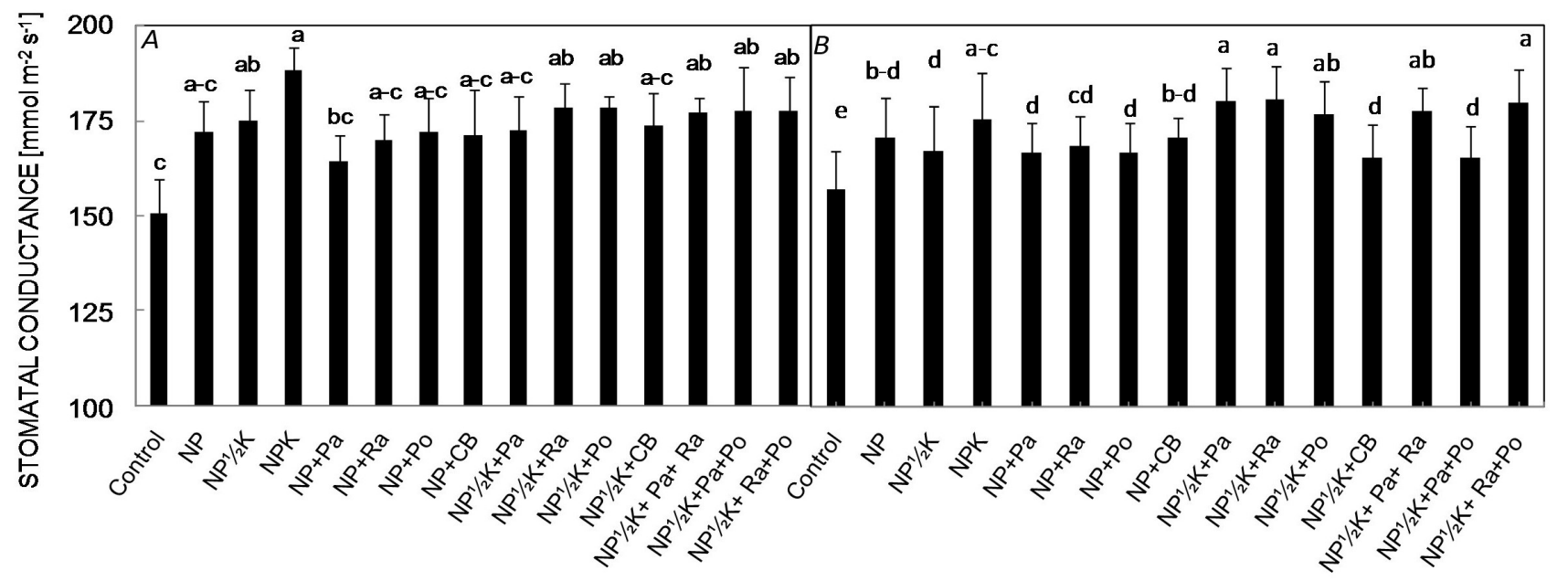

DIFFERENT LEVELS OF POTASSIUM FERTILIZER AND BACTERIA INOCULATION

Fig. 2. The response of stomatal conductance to potassium solubilizing bacteria (KSB) inoculations and K chemical fertilizer application in pot $(A)$ and field $(B)$ experiments. Means in each experiment followed by the same letter $(s)$ are not significantly different based on the least significant difference (LSD) test at 0.05 probability level.

Stomatal conductance and photosynthetic pigment contents: The $g_{\mathrm{s}}$ varied from 150.7 (control) to $188.3 \mathrm{mmol}$ $\mathrm{m}^{-2} \mathrm{~s}^{-1}$ (NPK) in the pots, and 214 (control) to $261.5 \mathrm{mmol}$ $\mathrm{m}^{-2} \mathrm{~s}^{-1}(\mathrm{NP} 1 / 2 \mathrm{~K}+R a)$ in the field experiment (Fig. 2). The highest amounts of Chl $a$ were 8.1 and $8.3 \mathrm{mg} \mathrm{g}^{-1}(\mathrm{FM})$ at NPK application in the pot and field experiments, respectively. Nevertheless, there were no statistically significant differences between NPK and NP1/2K+Ra treatment in both experiments and $\mathrm{NP}^{1} / 2 \mathrm{~K}+P a+P o$ treatment in the field. Accordingly, $\mathrm{Chl}(a+b)$ reached the maximum value equal to 10.46 and $10.70 \mathrm{mg} \mathrm{g}^{-1}(\mathrm{FM})$ in NPK treatment which was about 25.4 and $20.5 \%$ more than the control (-NPK) in the pot and field experiments, respectively (Fig. $3 A, E$ ). The difference was not statistically significant between all of the treatments in term of Chl $b$ and Chl $a / b$ in both experiments (Table 1). These values varied from 1.82 to 2.30 and 3.18 to $3.62 \mathrm{mg} \mathrm{g}^{-1}(\mathrm{FM})$ in the pot, and from 1.95 to 2.41 and 3.12 to $3.70 \mathrm{mg} \mathrm{g}^{-1}(\mathrm{FM})$ in the field experiment, respectively. Also, KSB inoculations, alone or combined with NPK fertilizer treatment, decreased the Car content in both experiments (Table 1). There was an increasing trend in the SPAD value by application of chemical fertilizer and KSB inoculations as compared to the control (Table 1).

Chl fluorescence parameters: As observed for ChlF, all the considered parameters, except for $\mathrm{F}_{\mathrm{v}} / \mathrm{F}_{\mathrm{m}}, \mathrm{Y}_{(\mathrm{NO})}$ in both experiments, and for $\mathrm{q}_{\mathrm{L}}$ in the pots, were affected by treatments. However, KSB inoculations, alone or combined with $\mathrm{K}$ fertilizer, significantly increased the value of ETR as compared to the control, but the highest value was obtained from NPK chemical fertilizer equal to 7.22 in the pot and 7.37 in the field experiment (Fig. 3C, G). On the other hand, there was not statistically significant difference between treatments in term of $\mathrm{F}_{\mathrm{v}} / \mathrm{F}_{\mathrm{m}}$ and $\mathrm{Y}_{(\mathrm{NO})}$. These values varied from 0.777 (control) to 0.804 (NPK) and $0.057\left(\mathrm{NP}^{1 / 2} \mathrm{~K}\right)$ to 0.066 (control) in the pot and from 0.783 (control) to $0.810(\mathrm{NP}+P o)$ and $0.053(\mathrm{NP} 1 / 2 \mathrm{~K}+P o)$ to 0.068 (control) in the field experiment, respectively (Table 2, Fig. 3B,F). Application of KSB inoculations and $\mathrm{K}$ fertilizer also induced $\mathrm{Y}_{(\mathrm{NPQ})}$ and NPQ to decrease significantly as compared to the control. The minimum value of $\mathrm{Y}_{(\mathrm{NPQ})}(0.14)$ and NPQ (1.5) were recorded by NPK treatment application in the pot experiment. Nevertheless, in the field experiment, these parameters reached the lowest value equivalent to 0.14 (NPK) and $1.5\left(\mathrm{NP}^{1} / 2 \mathrm{~K}+R a+P o\right)$ which was 0.66 and 0.92 times as much as those in control (Fig. $3 B, C, F, G$ ). The highest value of $\mathrm{q}_{\mathrm{N}}$ was obtained from the control in both experiments ( 0.718 and 0.720 , respectively). In opposite, the minimum $\mathrm{q}_{\mathrm{P}}$ was belonging to the control treatment which was significantly lower than the inoculation and chemical fertilization treatments in both experiments. The $\mathrm{NP}^{1} / 2 \mathrm{~K}+\mathrm{Po}$ treatment had the greatest impact on $\mathrm{q}_{\mathrm{L}}$ in the field experiment which was 1.28 and 1.17 times those in the control and NP treatments, respectively. Nevertheless, there was no statistically significant difference between treatments in terms of $\mathrm{q}_{\mathrm{L}}$ in the pot experiments (Table 1). In the pot experiments, the highest value of $\Phi_{\mathrm{PSI}}$ was observed under NPK treatment (0.798) which was $10.8 \%$ more than that in the control. The field experiment results indicated that the inoculation with $P$. orientalis coupled with $1 / 2 \mathrm{~K}$ fertilizer $\left(\mathrm{NP}^{1 / 2} \mathrm{~K}+P o\right)$ had more positive effects on $\Phi_{\mathrm{PSII}}$ than other treatments. Accordingly, the value of $\Phi_{\text {PSII }}$ varied from 0.711 to 0.796 in the field experiment (Fig. $3 D, H$ ).

Correlation and regression analysis: The Pearson's correlation coefficients showed that there were highly significant correlations between the $\mathrm{K}$ concentration in straw and Chl $a$, SPAD value, $g_{\mathrm{s}}, \mathrm{Y}_{(\mathrm{NO})}, \mathrm{ETR}, \mathrm{q}_{\mathrm{N}}, \mathrm{F}_{\mathrm{v}} / \mathrm{F}_{\mathrm{m}}$, $\Phi_{\text {PSII }}$, and grain yield in both experiments, NPQ in the pot experiment and $\mathrm{Y}_{(\mathrm{NPQ})}, \mathrm{q}_{\mathrm{P}}$ and $\mathrm{q}_{\mathrm{L}}$ in the field experiment (Table 2). The results of multiple linear regressions between grain yield and some main parameters of ChlF are shown in the Table 3. This multiple linear regression model with eight explanatory variables had an $\mathrm{R}$ squared 


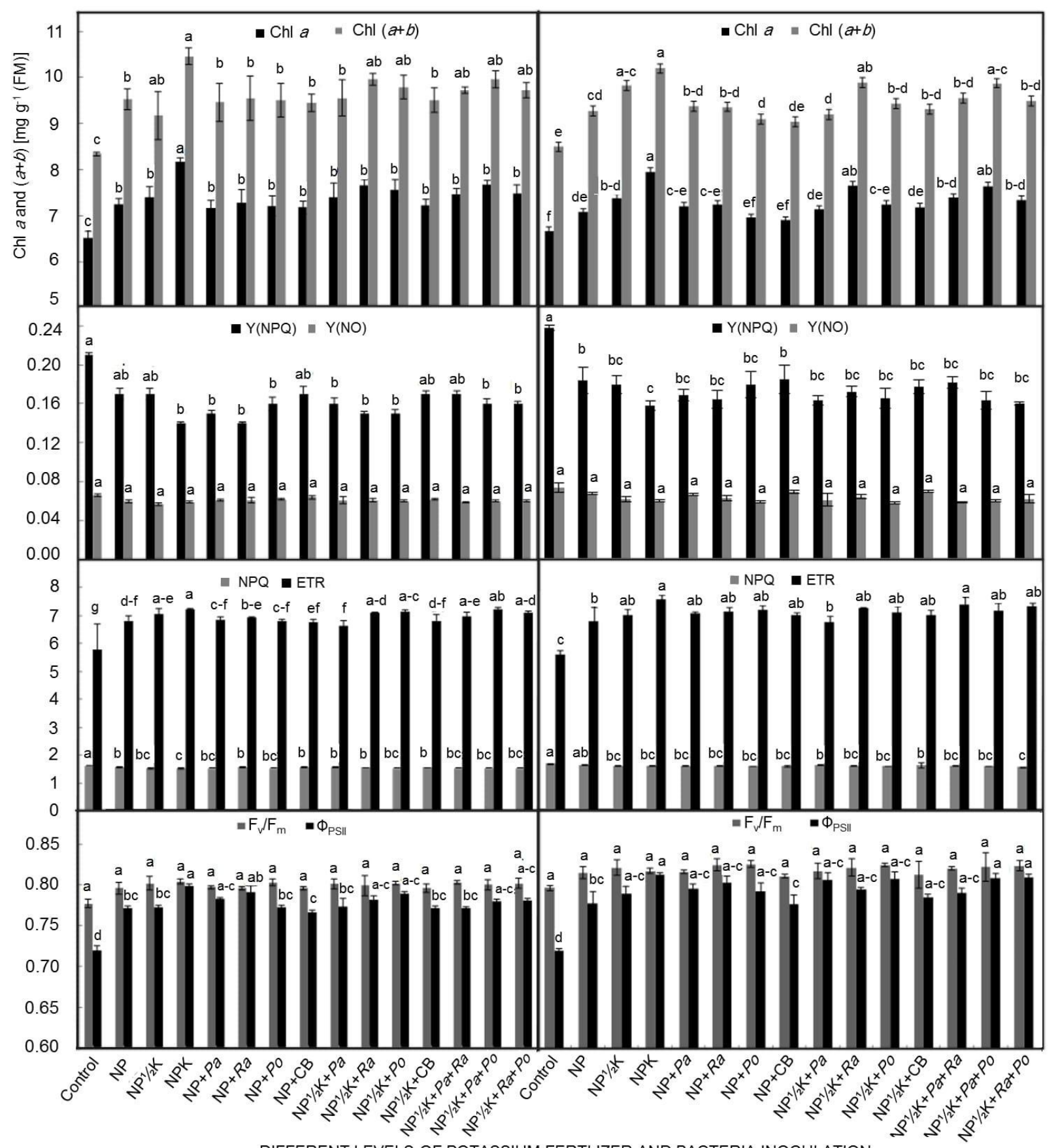

Fig. 3. The response of chlorophyll $a(\mathrm{Chl} a)$, total chlorophyll $(a+b)(A, E)$, quantum yield of light induced nonphotochemical quenching $\left(\mathrm{Y}_{(\mathrm{NPQ})}\right)$, quantum yield of regulated energy dissipation $\left(\mathrm{Y}_{(\mathrm{NO})}\right)(B, F)$, nonphotochemical quenching $(\mathrm{NPQ})$, electron transport rate (ETR) $(C, G)$, photochemical efficiency of PSII $\left(\mathrm{F}_{\mathrm{v}} / \mathrm{F}_{\mathrm{m}}\right)$ and effective quantum efficiency of PSII $\left(\Phi_{\mathrm{PSII}}\right)(D, H)$ to potassium solubilizing bacteria (KSB) inoculations and K chemical fertilizer application in pot (left panel) and field (right panel) experiments. Means in each trait and each experiment followed by the same letter $(s)$ are not significantly different based on the least significant difference (LSD) test at 0.05 probability level.

value of 0.894 and 0.895 in the pot and field experiments, respectively. Therefore, 89.4 and $89.5 \%$ of the variation in $\%$ grain yield can be explained by this model. According to the results, linear regression significantly was fitted to model the relationship between stomatal conductance and
ETR at the anthesis stage in the pot $(P<0.01)$ and field $(P<0.05)$ experiments. These coefficients of determination $\left(r^{2}\right)$ of the equations were 0.63 and 0.29 in the pot and field experiments, respectively (Fig. 4). 
Table 1. Amount of chlorophyll $b(\mathrm{Chl} b)$, ratio of $\mathrm{Chl} a / b$, carotenoid content, SPAD value, coefficient of photochemical fluo-rescence quenching based on a model of separate photosynthetic units $\left(\mathrm{q}_{\mathrm{P}}\right)$, coefficient of nonphotochemical fluorescence quenching ( $\mathrm{q}_{\mathrm{N}}$ ), and coefficient of photochemical fluorescence quenching assuming that all reaction centers share a common light-harvesting antenna $\left(\mathrm{q}_{\mathrm{L}}\right)$, as influenced by KSB inoculations and K chemical fertilization in rice. Values are means $\pm \mathrm{SE}, n=3$. Means in each column and each experiment followed by the same letter( $s$ ) are not significantly different based on the least significant difference (LSD) test at 0.05 probability level. *, ** - significant at $P<0.05$ and $P<0.01$ levels, respectively; ns - not significant.

\begin{tabular}{|c|c|c|c|c|c|c|c|}
\hline Treatments & $\begin{array}{l}\text { Chl } b \\
{\left[\mathrm{mg} \mathrm{g}^{-1}(\mathrm{FM})\right]}\end{array}$ & $\mathrm{Chl} a / b$ & $\begin{array}{l}\text { Carotenoids } \\
{\left[\mathrm{mg} \mathrm{g}^{-1}(\mathrm{FM})\right]}\end{array}$ & SPAD & $\mathrm{q}_{\mathrm{P}}$ & $\mathrm{q}_{\mathrm{L}}$ & $\mathrm{q}_{\mathrm{N}}$ \\
\hline \multicolumn{8}{|l|}{ Pot experiment } \\
\hline Control (-NPK) & $1.82 \pm 0.11^{\mathrm{a}}$ & $3.62 \pm 0.31^{\mathrm{a}}$ & $1.67 \pm 0.06^{\mathrm{ab}}$ & $36.37 \pm 0.11^{\mathrm{d}}$ & $0.926 \pm 0.007^{\mathrm{c}}$ & $2.303 \pm 0.079^{\mathrm{a}}$ & $0.718 \pm 0.002^{\mathrm{a}}$ \\
\hline NP & $2.28 \pm 0.11^{\mathrm{a}}$ & $3.19 \pm 0.11^{\mathrm{a}}$ & $1.69 \pm 0.05^{\mathrm{a}}$ & $40.57 \pm 0.17^{\mathrm{a}-\mathrm{c}}$ & $0.968 \pm 0.008^{\mathrm{ab}}$ & $2.496 \pm 0.068^{\mathrm{a}}$ & $0.704 \pm 0.001^{\mathrm{ab}}$ \\
\hline $\mathrm{NP}^{1} / 2 \mathrm{~K}$ & $2.31 \pm 0.35^{\mathrm{a}}$ & $3.32 \pm 0.41^{\mathrm{a}}$ & $1.55 \pm 0.05^{\mathrm{a}-\mathrm{c}}$ & $41.53 \pm 0.28^{\mathrm{ab}}$ & $0.963 \pm 0.011^{\mathrm{ab}}$ & $2.548 \pm 0.137^{\mathrm{a}}$ & $0.697 \pm 0.002^{\mathrm{b}}$ \\
\hline NPK & $2.30 \pm 0.08^{\mathrm{a}}$ & $3.55 \pm 0.09^{\mathrm{a}}$ & $1.47 \pm 0.11^{\mathrm{a}-\mathrm{c}}$ & $42.25 \pm 0.57^{\mathrm{a}}$ & $0.992 \pm 0.008^{\mathrm{a}}$ & $2.519 \pm 0.106^{\mathrm{a}}$ & $0.691 \pm 0.001^{b}$ \\
\hline $\mathrm{NP}+P a$ & $2.30 \pm 0.26^{\mathrm{a}}$ & $3.18 \pm 0.29^{\mathrm{a}}$ & $1.50 \pm 0.03^{\mathrm{a}-\mathrm{c}}$ & $40.31 \pm 0.18^{\mathrm{a}-\mathrm{c}}$ & $0.982 \pm 0.002^{\mathrm{ab}}$ & $2.491 \pm 0.022^{\mathrm{a}}$ & $0.699 \pm 0.001^{b}$ \\
\hline $\mathrm{NP}+R a$ & $2.25 \pm 0.23^{\mathrm{a}}$ & $3.29 \pm 0.29^{\mathrm{a}}$ & $1.49 \pm 0.12^{\mathrm{a}-\mathrm{c}}$ & $41.14 \pm 0.21^{\mathrm{a}-\mathrm{c}}$ & $0.993 \pm 0.010^{\mathrm{a}}$ & $2.516 \pm 0.153^{\mathrm{a}}$ & $0.702 \pm 0.002^{\mathrm{ab}}$ \\
\hline $\mathrm{NP}+P o$ & $2.30 \pm 0.23^{\mathrm{a}}$ & $3.20 \pm 0.32^{\mathrm{a}}$ & $1.53 \pm 0.07^{\mathrm{a}-\mathrm{c}}$ & $40.90 \pm 0.57^{\mathrm{a}-\mathrm{c}}$ & $0.962 \pm 0.006^{\mathrm{ab}}$ & $2.321 \pm 0.066^{\mathrm{a}}$ & $0.696 \pm 0.000^{\mathrm{b}}$ \\
\hline $\mathrm{NP}+\mathrm{CB}$ & $2.27 \pm 0.13^{\mathrm{a}}$ & $3.18 \pm 0.20^{\mathrm{a}}$ & $1.36 \pm 0.07^{\mathrm{c}}$ & $39.29 \pm 0.13^{c}$ & $0.962 \pm 0.005^{\mathrm{ab}}$ & $2.320 \pm 0.072^{\mathrm{a}}$ & $0.702 \pm 0.002^{\mathrm{ab}}$ \\
\hline $\mathrm{NP}^{1 / 2 \mathrm{~K}}+P a$ & $2.14 \pm 0.27^{\mathrm{a}}$ & $3.57 \pm 0.47^{\mathrm{a}}$ & $1.41 \pm 0.09^{\mathrm{bc}}$ & $40.70 \pm 0.52^{\mathrm{a}-\mathrm{c}}$ & $0.966 \pm 0.018^{\mathrm{ab}}$ & $2.416 \pm 0.275^{\mathrm{a}}$ & $0.700 \pm 0.002^{\mathrm{b}}$ \\
\hline $\mathrm{NP}^{1} / 2 \mathrm{~K}+R a$ & $2.29 \pm 0.09^{\mathrm{a}}$ & $3.35 \pm 0.16^{\mathrm{a}}$ & $1.39 \pm 0.112^{\mathrm{c}}$ & $42.01 \pm 0.39^{\mathrm{ab}}$ & $0.979 \pm 0.019^{\mathrm{ab}}$ & $2.443 \pm 0.222^{\mathrm{a}}$ & $0.700 \pm 0.006^{\mathrm{b}}$ \\
\hline $\mathrm{NP}^{1 / 2} \mathrm{~K}+P_{o}$ & $2.24 \pm 0.05^{\mathrm{a}}$ & $3.36 \pm 0.12^{\mathrm{a}}$ & $1.42 \pm 0.13^{\mathrm{bc}}$ & $41.90 \pm 0.37^{\mathrm{ab}}$ & $0.983 \pm 0.001^{\mathrm{ab}}$ & $2.464 \pm 0.020^{\mathrm{a}}$ & $0.697 \pm 0.000^{\mathrm{b}}$ \\
\hline $\mathrm{NP}^{1} / 2 \mathrm{~K}+\mathrm{CB}$ & $2.28 \pm 0.14^{\mathrm{a}}$ & $3.18 \pm 0.15^{\mathrm{a}}$ & $1.48 \pm 0.08^{\mathrm{a}-\mathrm{c}}$ & $40.02 \pm 0.25^{\mathrm{bc}}$ & $0.968 \pm 0.005^{\mathrm{ab}}$ & $2.398 \pm 0.046^{\mathrm{a}}$ & $0.702 \pm 0.002^{\mathrm{ab}}$ \\
\hline $\mathrm{NP}^{1} / 2 \mathrm{~K}+P a+R a$ & $2.26 \pm 0.06^{\mathrm{a}}$ & $3.31 \pm 0.13^{\mathrm{a}}$ & $1.55 \pm 0.11^{\mathrm{a}-\mathrm{c}}$ & $40.40 \pm 0.68^{\mathrm{a}-\mathrm{c}}$ & $0.959 \pm 0.004^{\mathrm{b}}$ & $2.442 \pm 0.052^{\mathrm{a}}$ & $0.697 \pm 0.000^{\mathrm{b}}$ \\
\hline $\mathrm{NP}^{1} / 2 \mathrm{~K}+P a+P o$ & $2.29 \pm 0.19^{\mathrm{a}}$ & $3.39 \pm 0.31^{\mathrm{a}}$ & $1.51 \pm 0.09^{\mathrm{a}-\mathrm{c}}$ & $42.20 \pm 0.47^{\mathrm{a}}$ & $0.975 \pm 0.007^{\mathrm{ab}}$ & $2.480 \pm 0.064^{\mathrm{a}}$ & $0.698 \pm 0.002^{\mathrm{b}}$ \\
\hline $\mathrm{NP}^{1} / 2 \mathrm{~K}+R a+P o$ & $2.25 \pm 0.02^{\mathrm{a}}$ & $3.33 \pm 0.10^{\mathrm{a}}$ & $1.33 \pm 0.13^{\mathrm{c}}$ & $39.26 \pm 0.59^{c}$ & $0.979 \pm 0.011^{\mathrm{ab}}$ & $2.460 \pm 0.134^{\mathrm{a}}$ & $0.697 \pm 0.002^{\mathrm{b}}$ \\
\hline \multicolumn{8}{|c|}{$A N O V A$ (Mean square) } \\
\hline $\mathrm{K}$ treatments & $0.046^{\text {ns }}$ & $0.064^{\mathrm{ns}}$ & $0.031^{*}$ & $6.872^{* *}$ & $0.001^{*}$ & $0.020^{\mathrm{ns}}$ & $0.000^{*}$ \\
\hline \multicolumn{8}{|l|}{ Field experiment } \\
\hline Control (-NPK) & $1.95 \pm 0.11^{\mathrm{a}}$ & $3.58 \pm 0.21^{\mathrm{a}}$ & $1.74 \pm 0.02^{\mathrm{a}}$ & $37.39 \pm 1.02^{\mathrm{c}}$ & $0.908 \pm 0.012^{\mathrm{b}}$ & $2.134 \pm 0.101^{\mathrm{c}}$ & $0.720 \pm 0.002^{\mathrm{a}}$ \\
\hline NP & $2.35 \pm 0.11^{\mathrm{a}}$ & $3.14 \pm 0.10^{\mathrm{a}}$ & $1.55 \pm 0.11^{\mathrm{a}-\mathrm{c}}$ & $41.60 \pm 0.88^{\mathrm{a}-\mathrm{c}}$ & $0.957 \pm 0.009^{\mathrm{a}}$ & $2.332 \pm 0.074^{\mathrm{bc}}$ & $0.704 \pm 0.001^{\mathrm{ab}}$ \\
\hline $\mathrm{NP}^{1} / 2 \mathrm{~K}$ & $2.41 \pm 0.36^{\mathrm{a}}$ & $3.41 \pm 0.46^{\mathrm{a}}$ & $1.61 \pm 0.04^{\mathrm{ab}}$ & $43.33 \pm 1.12^{\mathrm{ab}}$ & $0.963 \pm 0.10^{\mathrm{a}}$ & $2.518 \pm 0.106^{\mathrm{ab}}$ & $0.698 \pm 0.004^{\mathrm{ab}}$ \\
\hline NPK & $2.40 \pm 0.08^{\mathrm{a}}$ & $3.46 \pm 0.08^{\mathrm{a}}$ & $1.33 \pm 0.07^{\mathrm{cd}}$ & $43.31 \pm 1.70^{\mathrm{ab}}$ & $0.995 \pm 0.013^{\mathrm{a}}$ & $2.736 \pm 0.176^{\mathrm{a}}$ & $0.692 \pm 0.001^{\mathrm{b}}$ \\
\hline $\mathrm{NP}+\mathrm{Pa}$ & $2.32 \pm 0.18^{\mathrm{a}}$ & $3.26 \pm 0.24^{\mathrm{a}}$ & $1.40 \pm 0.02^{\mathrm{b}-\mathrm{d}}$ & $41.18 \pm 1.04^{\mathrm{a}-\mathrm{c}}$ & $0.976 \pm 0.011^{\mathrm{a}}$ & $2.405 \pm 0.103^{\mathrm{a}-\mathrm{c}}$ & $0.700 \pm 0.001^{\mathrm{ab}}$ \\
\hline $\mathrm{NP}+R a$ & $2.27 \pm 0.19^{\mathrm{a}}$ & $3.36 \pm 0.30^{\mathrm{a}}$ & $1.46 \pm 0.03^{\mathrm{b}-\mathrm{d}}$ & $42.07 \pm 1.14^{\mathrm{ab}}$ & $0.975 \pm 0.014^{\mathrm{a}}$ & $2.474 \pm 0.163^{\mathrm{a}-\mathrm{c}}$ & $0.696 \pm 0.002^{\mathrm{ab}}$ \\
\hline $\mathrm{NP}+\mathrm{Po}_{0}$ & $2.30 \pm 0.16^{\mathrm{a}}$ & $3.17 \pm 0.24^{\mathrm{a}}$ & $1.29 \pm 0.02^{\mathrm{d}}$ & $41.82 \pm 0.94^{\mathrm{ab}}$ & $0.961 \pm 0.010^{\mathrm{a}}$ & $2.599 \pm 0.214^{\mathrm{ab}}$ & $0.694 \pm 0.002^{\mathrm{ab}}$ \\
\hline $\mathrm{NP}+\mathrm{CB}$ & $2.31 \pm 0.09^{\mathrm{a}}$ & $3.12 \pm 0.17^{\mathrm{a}}$ & $1.37 \pm 0.11^{\mathrm{b}-\mathrm{d}}$ & $40.03 \pm 0.70^{\mathrm{bc}}$ & $0.959 \pm 0.008^{\mathrm{a}}$ & $2.321 \pm 0.117^{\mathrm{bc}}$ & $0.700 \pm 0.004^{\mathrm{ab}}$ \\
\hline $\mathrm{NP}^{1} / 2 \mathrm{~K}+P a$ & $2.21 \pm 0.29^{\mathrm{a}}$ & $3.48 \pm 0.52^{\mathrm{a}}$ & $1.39 \pm 0.16^{\mathrm{b}-\mathrm{d}}$ & $42.23 \pm 1.17^{\mathrm{ab}}$ & $0.987 \pm 0.016^{\mathrm{a}}$ & $2.646 \pm 0.273^{\mathrm{ab}}$ & $0.702 \pm 0.002^{\mathrm{ab}}$ \\
\hline $\mathrm{NP}^{1 / 2 \mathrm{~K}}+R a$ & $2.39 \pm 0.09^{\mathrm{a}}$ & $3.46 \pm 0.12^{\mathrm{a}}$ & $1.28 \pm 0.13^{\mathrm{d}}$ & $45.33 \pm 0.90^{\mathrm{a}}$ & $0.969 \pm 0.020^{\mathrm{a}}$ & $2.463 \pm 0.284^{\mathrm{a}-\mathrm{c}}$ & $0.696 \pm 0.007^{\mathrm{ab}}$ \\
\hline $\mathrm{NP}^{1 / 2} \mathrm{~K}+P_{o}$ & $2.35 \pm 0.04^{\mathrm{a}}$ & $3.21 \pm 0.09^{\mathrm{a}}$ & $1.34 \pm 0.09^{\mathrm{cd}}$ & $43.69 \pm 1.29^{\mathrm{ab}}$ & $0.979 \pm 0.020^{\mathrm{a}}$ & $2.745 \pm 0.359^{\mathrm{a}}$ & $0.693 \pm 0.001^{b}$ \\
\hline $\mathrm{NP}^{1} / 2 \mathrm{~K}+\mathrm{CB}$ & $2.27 \pm 0.14^{\mathrm{a}}$ & $3.30 \pm 0.12^{\mathrm{a}}$ & $1.36 \pm 0.10^{\text {cd }}$ & $42.89 \pm 1.81^{\mathrm{ab}}$ & $0.967 \pm 0.010^{\mathrm{a}}$ & $2.322 \pm 0.071^{\mathrm{bc}}$ & $0.702 \pm 0.002^{\mathrm{ab}}$ \\
\hline $\mathrm{NP}^{1} / 2 \mathrm{~K}+P a+R a$ & $2.32 \pm 0.02^{\mathrm{a}}$ & $3.32 \pm 0.11^{\mathrm{a}}$ & $1.56 \pm 0.14^{\mathrm{a}-\mathrm{c}}$ & $41.64 \pm 1.49^{\mathrm{a}-\mathrm{c}}$ & $0.964 \pm 0.012^{\mathrm{a}}$ & $2.656 \pm 0.185^{\mathrm{ab}}$ & $0.699 \pm 0.003^{\mathrm{ab}}$ \\
\hline $\mathrm{NP}^{1} / 2 \mathrm{~K}+P a+P o$ & $2.40 \pm 0.21^{\mathrm{a}}$ & $3.70 \pm 0.27^{\mathrm{a}}$ & $1.37 \pm 0.09^{\mathrm{b}-\mathrm{d}}$ & $43.59 \pm 1.05^{\mathrm{ab}}$ & $0.984 \pm 0.011^{\mathrm{a}}$ & $2.683 \pm 0.183^{\mathrm{ab}}$ & $0.694 \pm 0.000^{\mathrm{ab}}$ \\
\hline $\mathrm{NP}^{1} / 2 \mathrm{~K}+R a+P_{o}$ & $2.29 \pm 0.06^{\mathrm{a}}$ & $3.34 \pm 0.08^{\mathrm{a}}$ & $1.29 \pm 0.08^{\mathrm{d}}$ & $41.73 \pm 1.34^{\mathrm{ab}}$ & $0.983 \pm 0.004^{\mathrm{a}}$ & $2.574 \pm 0.184^{\mathrm{ab}}$ & $0.697 \pm 0.002^{\mathrm{ab}}$ \\
\hline \multicolumn{8}{|c|}{$A N O V A$ (Mean square) } \\
\hline $\mathrm{K}$ treatments & $0.039^{\mathrm{ns}}$ & $0.052^{\mathrm{ns}}$ & $0.054^{*}$ & $10.02^{*}$ & $0.001^{*}$ & $0.096^{*}$ & $0.000^{*}$ \\
\hline
\end{tabular}

\section{Discussion}

Based on our previous research, $P$. agglomerans, $R$. aquatilis, and $P$. orientalis solubilized about 45 and $60 \mu \mathrm{g} \mathrm{ml}^{-1}$ of $\mathrm{K}$ from insoluble $\mathrm{K}$-bearing mineral source (mica powder) after $28 \mathrm{~d}$ from inoculation, respectively (more details in Yaghoubi Khanghahi et al. 2018b). The current study was performed to assess the potential effects of these KSB strains (applied alone or combined with half the recommended dose of the $\mathrm{K}$ chemical fertilizer) to improve the leaf photosynthetic capacity of rice. The results showed that the KSB inoculations not only enhanced the rice $\mathrm{K}$ accumulation, but also increased the grain yield, especially, when they were applied with $1 / 2 \mathrm{~K}$ chemical fertilizer. These findings are in agreement with Bakhshandeh et al. (2018), who reported that the mineral 
Table 2. Pearson's correlation coefficients $(r)$ between K uptake by straw and different photosynthetic variables and grain yield as influenced by KSB inoculations and $\mathrm{K}$ chemical fertilizer application $(n=15)$. Chl $a$ - chlorophyll $a ; \mathrm{Y}_{(\mathrm{NPQ})}-$ quantum yield of light-induced nonphotochemical quenching; $\mathrm{Y}_{(\mathrm{NO})}$ - quantum yield of regulated energy dissipation; NPQ - nonphotochemical quenching; ETR - photosynthetic electron transport rate; $\mathrm{q}_{\mathrm{P}}-$ coefficient of photochemical fluorescence quenching based on a model of separate photosynthetic units; $\mathrm{q}_{\mathrm{N}}$ - coefficient of nonphotochemical fluorescence quenching; $\mathrm{q}_{\mathrm{L}}$ - coefficient of photochemical fluorescence quenching assuming that all reaction centers share a common light-harvesting antenna; $\mathrm{F}_{\mathrm{v}} / \mathrm{F}_{\mathrm{m}}-$ maximum quantum yield of photosystem II; $\Phi_{\text {PSII }}-$ effective quantum efficiency of PSII. * and ** - significant at $P<0.05$ and $P<0.01$ levels, respectively; ns- not significant.

\begin{tabular}{lcc}
\hline Variable & $r$ (pot experiment) & $r$ (field experiment) \\
\hline Chl $a$ & $0.814^{* *}$ & $0.825^{* *}$ \\
Carotenoids & $-0.418^{\text {ns }}$ & $-0.462^{\text {ns }}$ \\
SPAD value & $0.602^{*}$ & $0.715^{* *}$ \\
Stomatal conductance & $0.775^{* *}$ & $0.666^{* *}$ \\
Y $_{\text {(NPQ) }}$ & $-0.464^{\text {ns }}$ & $-0.631^{*}$ \\
$\mathrm{Y}_{\text {(NO) }}$ & $-0.565^{*}$ & $-0.686^{* *}$ \\
NPQ & $-0.633^{*}$ & $-0.491^{\text {ns }}$ \\
ETR & $0.664^{*}$ & $0.653^{* *}$ \\
q $_{\mathrm{P}}$ & $0.437^{\text {ns }}$ & $0.682^{* *}$ \\
q $_{\mathrm{N}}$ & $-0.620^{*}$ & $-0.609^{*}$ \\
$\mathrm{q}_{\mathrm{L}}$ & $0.388^{\mathrm{ns}}$ & $0.770^{* *}$ \\
$\mathrm{~F}_{\mathrm{v}} / \mathrm{F}_{\mathrm{m}}$ & $0.605^{*}$ & $0.538^{*}$ \\
$\Phi_{\mathrm{PSII}}$ & $0.531^{*}$ & $0.658^{* *}$ \\
Grain yield & $0.839^{* *}$ & $0.788^{* *}$ \\
\hline
\end{tabular}

(2018a) showed that rice plants inoculated with KSB had higher $\mathrm{K}$ concentration in grain as compared to the noninoculated plants. Previous investigations have shown that the nutrient uptake by rice plant was in response to inoculations with K-solubilizing microorganisms signifantly increased through both direct (the ability of solubilizing insoluble silicate compounds minerals in the rhizosphere and plant hormone production) and indirect mechanisms (synthesis of antibiotics, enzymes, fungicidal compounds, and competition with detrimental microorganisms) (Bakhshandeh et al. 2015, Priyanka et al. 2017).

In the present study, photosynthetic pigments [Chl $a$, Chl $(a+b)$, and Car] and SPAD value were affected by application of NPK fertilizer and KSB inoculations. Accordingly, low $\mathrm{K}$ resulted in decreased contents of $\mathrm{Chl} a$ and SPAD value in plants under the control and NP treatments. Similarly, Shah et al. (2017) investigated the Chl and SPAD measurement during nutrient stress in wheat and reported that the limited nutrient supply resulted in decreased pigment content per unit area, as well as in the total amount produced per plant. It has already been reported that the optimal N, P, and K supply is considered essential for the biosynthesis of plant photosynthetic pigments (Yong et al. 2010). Furthermore, $\mathrm{K}$ is the most abundant cellular cation and plays important roles in plant cellular homeostasis by contributing to charge balance, osmotic adjustment, and enzyme catalysis (Marschner 1995). On the other hand, linear models related to SPAD value and rice leaf $\mathrm{Chl}$ content at anthesis time were determined with high coefficients of determination in the pot $\left(r^{2}=0.69\right)$ and field $\left(r^{2}=0.60\right)$ experiments (data not shown). This finding supports the results of other studies by Wakiyama (2016) and

Table 3. Multiple linear regressions (enter method) between grain yield and some photosynthetic variables in rice under KSB inoculations and $\mathrm{K}$ chemical fertilizer application. Chl $a$-chlorophyll $a ; \mathrm{F}_{\mathrm{v}} / \mathrm{F}_{\mathrm{m}}-$ maximum quantum yield of PSII; $\Phi_{\mathrm{PSII}}-$ effective quantum efficiency of PSII; $Y_{(\mathrm{NPQ})}$ - quantum yield of light-induced nonphotochemical quenching; NPQ - nonphotochemical quenching; $\mathrm{q}_{\mathrm{P}}-\mathrm{coefficient}$ of photochemical fluorescence quenching based on a model of separate photosynthetic units; $\mathrm{q}_{\mathrm{N}}$ - coefficient of nonphotochemical fluorescence quenching; ETR - photosynthetic electron transport rate. * and ** - significant at $P<0.05$ and $P<0.01$ levels, respectively; ns - not significant.

\begin{tabular}{|c|c|c|c|}
\hline \multirow[t]{2}{*}{ Dependent variable } & \multirow[t]{2}{*}{ Independent variables } & \multicolumn{2}{|c|}{ Standardized coefficients (Beta) } \\
\hline & & Pot & Field \\
\hline \multirow[t]{8}{*}{ Grain yield } & Chl $a$ & $0.67^{*}$ & $0.64^{*}$ \\
\hline & $\mathrm{F}_{\mathrm{v}} / \mathrm{F}_{\mathrm{m}}$ & $2.73^{*}$ & $7.53^{* *}$ \\
\hline & $\Phi_{\mathrm{PSII}}$ & $3.40^{*}$ & $24.82^{* *}$ \\
\hline & $\mathrm{Y}_{(\mathrm{NPQ})}$ & $-0.88^{\text {ns }}$ & $-3.04^{* *}$ \\
\hline & NPQ & $-2.40^{\mathrm{ns}}$ & $0.24^{\mathrm{ns}}$ \\
\hline & $\mathrm{q}_{\mathrm{p}}$ & $1.72^{\mathrm{ns}}$ & $-21.13^{* *}$ \\
\hline & $\mathrm{q}_{\mathrm{N}}$ & $3.69^{\text {ns }}$ & $0.54^{\mathrm{ns}}$ \\
\hline & ETR & $0.02^{\mathrm{ns}}$ & $0.35^{\mathrm{ns}}$ \\
\hline Adjusted R square & & $0.894^{* *}$ & $0.885^{* *}$ \\
\hline
\end{tabular}

nutrient uptake, especially $\mathrm{K}$, by plant enhanced under PGPR inoculation treatments. In this regard, Bakhshandeh et al. (2017) showed in rice that the PGPR inoculation significantly enhanced $\mathrm{K}$ uptake by leaves, stem, and roots up to 77,53 , and $75 \%$ as compared to the control, respectively. In other study, Yaghoubi Khanghahi et al.
Kumagai et al. (2009) in rice plant.

However, Shah et al. (2017) reported that the K fertilizer application enhanced $\mathrm{Chl}$ content and SPAD value as compared to that of the plants without fertilization, but the impact of KSB inoculations on photosynthetic pig- 


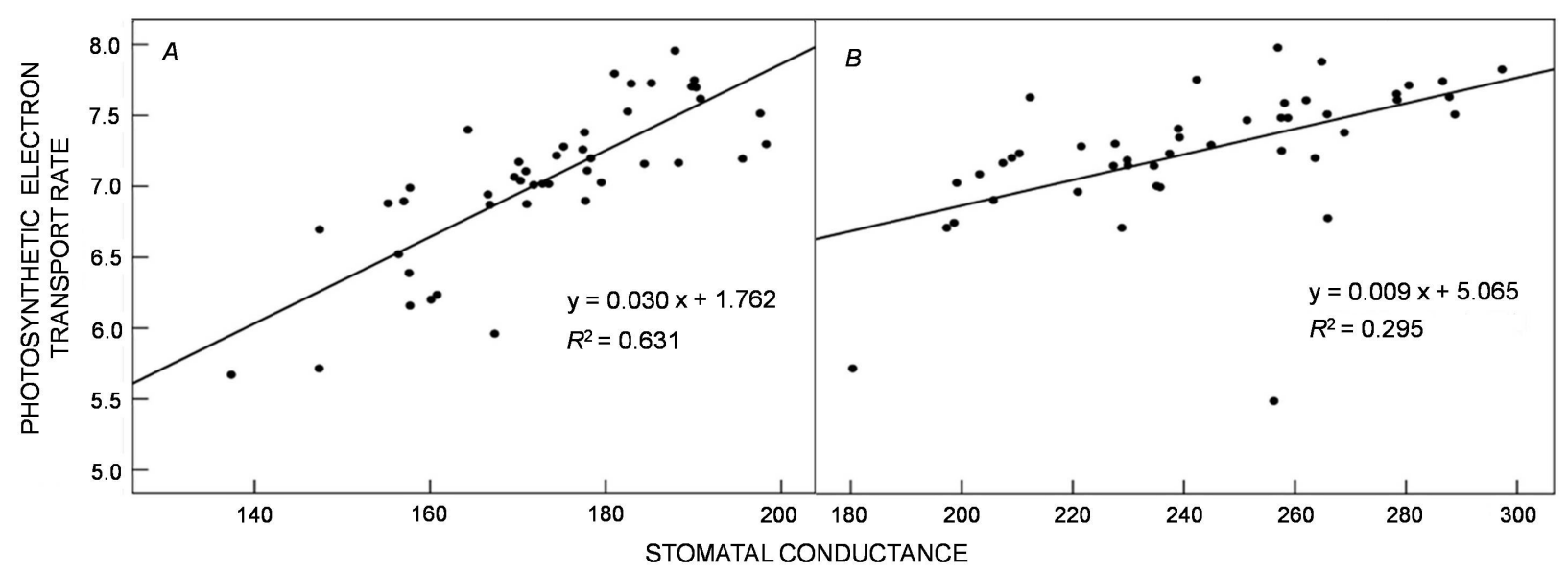

Fig. 4. The relationship between stomatal conductance and photosynthetic electron transport rate in response to potassium solubilizing bacteria (KSB) inoculations and $\mathrm{K}$ chemical fertilizer application in pot $(A)$ and field $(B)$ experiments.

ments, stomatal conductance, and ChlF in rice plants has not been characterized. Bakhshandeh et al. (2015) in a pot experiment studied the effects of phosphate-solubilizing bacteria (PSB) on rice seedlings and showed that the total $\mathrm{Chl}$ and Car contents increased by 8.5 and $9.2 \%$, respectively, when rice seeds were inoculated with the Enterobacter sp. as compared to the control. Similar results were presented by Panhwar et al. (2011), who reported that the leaf $\mathrm{Chl}$ content in rice was enhanced by Bacillus sp. inoculation. Bakhshandeh et al. (2018) also reported that SPAD value in rice seedlings increased by $8.6-12.0 \%$ under KSB inoculations as compared to noninoculated seedlings.

On the other hand, $\mathrm{Chl} b$ and $\mathrm{Chl} a / b$ showed no significant changes. This may be caused by the different sensitivity of Chl $a$ and $b$ under external environment (Sayyad-Amin et al. 2016). Previous study has also reported that the Chl $a$ may be 2 to 4 times higher than $\mathrm{Chl} b$, according to the growth stage and environmental conditions (Maina and Wang 2015).

Compared with the controls, the $g_{\mathrm{s}}$ in leaves increased by NPK fertilization and KSB inoculations. This result is in agreement with Jin et al. (2011) and Jia et al. (2008), who reported that the $g_{\mathrm{s}}$ and electron transfer energy in rice leaves increased under $\mathrm{K}$ fertilization. Zhao et al. (2016) also reported $\mathrm{K}$ deficiency disrupted the $g_{\mathrm{s}}$. In previous studies, the decrease in $g_{\mathrm{s}}$ was considered as the main action that depressed plant leaf photosynthetic capacity under K-deficient conditions (Peng et al. 2006).

The parameters of $\mathrm{Y}_{(\mathrm{NPQ})}, \mathrm{NPQ}$, and ETR were significantly affected by the applied treatments. Inoculation of KSB strains alone or combined with NPK chemical fertilizer increased ETR, while both $\mathrm{Y}_{(\mathrm{NPQ})}$ and NPQ decreased as compared to the control in both pot and field experiments. Ratio of $F_{v} / F_{m}$ was used for characterizing potential photochemical efficiency of PSII. This parameter is the maximum efficiency at which light absorbed by PSII is used for reduction of quinone $A\left(Q_{A}\right)$, as the first quinone acceptor, and is used as a sensitive indicator of plant photosynthetic performance (Maxwell and Johnson 2000).
The results in our study showed that the ratio of $\mathrm{F}_{\mathrm{v}} / \mathrm{F}_{\mathrm{m}}$ varied from 0.78 to 0.80 and 0.78 to 0.81 in the pot and field experiments, respectively. It has already been proved that the value of $F_{v} / F_{m}$ is usually from 0.79 (ChojakKozniewska et al. 2018) to 0.85 (Kalaji and Guo 2008) when seedlings are not influenced by environmental conditions. Accordingly, $\Phi_{\text {PSII }}$ significantly increased by inoculation and fertilization treatments as compared to the control. KSB inoculation and $\mathrm{K}$ fertilization could increase $\Phi_{\mathrm{PSII}}$ and maintain relatively high photochemical efficiency and strong photosynthetic capacity. This ratio is the one most widely used in research employing the fluorescence technique and is directly correlated with the photochemical efficiency of PSII (Torres Netto et al. 2002). Similarly, it has already been reported that the $\mathrm{F}_{\mathrm{v}} / \mathrm{F}_{\mathrm{m}}$ is known to be quite insensitive to many environmental stress factors, including nutrient deficiency (Živčák et al. 2008), while the effective quantum yield of PSII is far more responsive also to mild stress conditions (Salvatori et al. 2017). Since $\Phi_{\text {PSII }}$ is directly related to the $\mathrm{CO}_{2}$ assimilation rate (Kramer et al. 2004), increased $\Phi_{\mathrm{PSII}}$ in this study could lead to higher $\mathrm{CO}_{2}$ assimilation and contribute to enhanced grain yield.

The value of ETR significantly increased when the K uptake by straw increased by applied treatments. Maxwell and Johnson (2000) investigated the changes of ChlF under laboratory conditions and reported that the ETR value highly correlated with $\mathrm{CO}_{2}$ assimilation rate in crops. Therefore, in the present study, the increment of rice growth and grain yield under inoculation and $\mathrm{K}$ fertilization may be attributed to ETR enhancement and elevation of $\mathrm{CO}_{2}$ assimilation (Yaghoubian et al. 2016). According to the results, bacterial inoculants could increase the ETR value as compared to the control. This finding agrees with the results of Li et al. (2013), who reported that soil microorganisms could relieve the inhibition of the PSII reaction center and enhance the value of ETR, and then improve the process of photochemical and light transformation.

The $\mathrm{Y}_{(\mathrm{NPQ})}$ is the yield for dissipation by downregulation and $\mathrm{Y}_{(\mathrm{NO})}$ is the yield of other nonphotochemical losses and 
reflects no light-induced quenching processes (Kramer et al. 2004). According to the results, $\mathrm{Y}_{(\mathrm{NPQ})}$ in both pot and field experiments were sensitive to $\mathrm{K}$ deficiency in the control as compared to other treatment. It seems that $\mathrm{K}$ deficiency decreased the light-saturation points. In that condition, absorption of light energy by PS that was in excess of the capacity of the photosynthesis can lead to a significant increase of NPQ in the stressed leaves of rice. (Jia et al. 2008).

However, the results of several studies indicated that the photosynthetic capacities of higher plants change dramatically in response to different supplies of $\mathrm{K}$ (Weng et al. 2007, Jia et al. 2008), but we did not find any document that would report the effect of KSB on ChlF parameters. The underlying mechanisms of the effects of leaf $\mathrm{K}$ concentration on photosynthesis are still not fully understood; however, it has been suggested that the activity of Rubisco is an important limiting factor of photosynthesis in rice leaves (Weng et al. 2007). $\mathrm{K}$ affects the photosynthesis process at many levels, such as synthesis of ATP, activation of the enzymes involved in photosynthesis, $\mathrm{CO}_{2}$ uptake, balance of the electric charges required for photophosphorylation in chloroplasts and acting as the counter ion to light-induced $\mathrm{H}^{+}$flux across the thylakoid membranes (Marschner 1995).

The multiple linear regressions were used to explain which of the ChlF parameters could be more useful to predict the grain yield under the $\mathrm{K}$ fertilization and KSB inoculations in both experiments. Accordingly, $\mathrm{Chl} a, \mathrm{~F}_{\mathrm{v}} / \mathrm{F}_{\mathrm{m}}$, and $\Phi_{\mathrm{PSII}}$ in both experiments and $\mathrm{Y}_{(\mathrm{NPQ})}$ and $\mathrm{q}_{\mathrm{P}}$ in the field experiment can significantly affect the grain yield. Based on the correlation analysis results, $\mathrm{K}$ concentration in straw at anthesis showed a significant correlation with some parameters, such as $\mathrm{Chl} a, \Phi_{\mathrm{PSII}}$, and grain yield. These findings are in agreement with the results of Xue et al. (2016), who reported the positive correlations between $\mathrm{K}$ concentration in plant tissues and grain yield. Similarly, Ntanos and Koutroubas (2002) reported that the grain yield significantly correlated with nutrient uptake and concentration in rice plant. Bakhshandeh et al. (2015) also found an increase in leaf $\mathrm{Chl}$ content when rice seeds were inoculated with $R$. aquatilis. They reported these increases may have resulted in improved nutrient uptake, photosynthetic pigment contents, and finally an increase in the grain yield. These results are also in agreement with Jia et al. (2008), who showed the ChlF parameters were markedly affected by $\mathrm{K}$ deficiency. It means that any $\mathrm{K}$ deficiency likely leads to a reduced content of leaf pigments, retarded plant growth, and low net primary productivity (Zhang et al. 2003).

ETR seems to be more independent from $g_{\text {s }}$ in the field experiment as compared to the pots. In fact, ETR in pots were lowered more rapidly than in the field when $g_{s}$ decreased. It has been reported that the decrease of ETR led to the generation of excess excitation energy, which can exacerbate photoinhibition under stress (Wang et al. 2016). ETR is known as an indicator of electron transport to acceptors other than $\mathrm{CO}_{2}$ in alternative processes, such as photorespiration and Mehler reactions (Jiang et al. 2006). It seems that the rice plants grown in the field had a greater potential to maintain their ETR capability under lower $g_{\mathrm{s}}$ values and to replace photosynthesis with photorespiration as an electron-consuming process (Flexas et al. 2002) and a protective role against photoinhibition (Jiang et al. 2006) under K-deficient conditions.

There were some differences between the results achieved by the pot and field experiments in term of SPAD value, $g_{\mathrm{s}}, \mathrm{K}$ uptake by straw, grain yield, $\mathrm{Y}_{(\mathrm{NPQ})}, \mathrm{NPQ}$, and $\Phi_{\mathrm{PSII}}$. Accordingly, the lowest values of the $\mathrm{Y}_{(\mathrm{NPQ})}$ and NPQ parameters in the pot experiment were obtained with NPK, while the lowest values of these indices in the field experiment were obtained from $\mathrm{NP}^{1} / 2 \mathrm{~K}+P a+R a$ and $\mathrm{NP}^{1} / 2 \mathrm{~K}+R a+P o$ treatments, respectively. It seems that soil bacterial activities in the field experiment were higher than that in the pot experiment. The reason for this difference may be the use of sterilized soil in the pots. In addition, the pot experiments usually are performed under environmental conditions which seldom or never occur in the field experiments (de Vries 1980) such as stagnant flood conditions that could decrease microbial biomass and activity (Unger et al. 2009) and rice growth (Kuanar et al. 2017).

$R$. aquatilis and $P$. orientalis had greater impacts on photosynthetic pigments content and ChlF parameters (especially $\Phi_{\mathrm{PSII}}$ ) than other strains. Results also showed that the commercial $\mathrm{K}$ biofertilizer $(\mathrm{NP}+\mathrm{CB}$ and $\mathrm{NP} 1 / 2 \mathrm{~K}+\mathrm{CB}$ treatments) had lower effects on the studied traits, such as $\mathrm{K}$ concentration in straw, grain yield, ETR, $g_{\mathrm{s}}$, and $\Phi_{\mathrm{PSII}}$ than those in native KSB inoculations. This result could be explained by a lower adaptation to the crop microenvironmental conditions (Tabassum et al. 2017). Therefore, nonnative strains, when applied as a commercial biofertilizer, cannot compete with the existing native bacterial community for establishment and persistence in the soil. It has already been reported that the native PGPRs isolated from rhizospheric soil may be more useful than others because they are already competent, adapted, and dominant in a particular geographical area (Bergottini et al. 2015). Also, crops are defended both by chemicals and by specific immune responses to nonnative strains (Bever et al. 2012).

Based on the results, the three native KSB strains can be used as a viable alternative to increase $\mathrm{K}$ concentration in plants, especially when $1 / 2 \mathrm{~K}$ chemical fertilizer was applied. These findings are in agreement with the results of several studies that proved the application of PGPRs in nutrient management strategies aimed at decreasing chemical fertilizer consumption and consequently, promoting environmentally friendly crop production (Meena et al. 2017). It has already been reported that the application of biofertilizer can reduce the cost of $\mathrm{K}$ chemical fertilizers about 50 to $60 \%$ (Chandra et al. 2002) and enhance the $\mathrm{K}$ fertilizer efficiency (Bahadur et al. 2014).

In conclusion, the results of this study showed that the inoculation with three native KSB strains of $P$. agglomerans, $R$. aquatilis, and $P$. orientalis isolated from rice paddy soils could be considered as an effective way to enhance K uptake by rice seedlings, ChlF parameters, Chl $a$ content, and stomatal conductance. Therefore, these KSBs strains, as potential inoculants, can help to minimize use 
of $\mathrm{K}$ chemical fertilizer for rice production by increasing the efficiency of photosynthesis in the flooding irrigation conditions.

\section{References}

Bahadur I., Meena V.S., Kumar S.: Importance and application of potassic biofertilizer in Indian agriculture. - Int. Res. J. Biol. Sci. 3: 80-85, 2014.

Bakhshandeh E., Pirdashti H., Gilani Z.: Application of mathematical models to describe rice growth and nutrients uptake in the presence of plant growth promoting microorganisms. Appl. Soil Ecol. 124: 171-184, 2018.

Bakhshandeh E., Pirdashti H., Shahsavarpour Lendeh K.: Phosphate and potassium-solubilizing bacteria effect on the growth of rice. - Ecol. Eng. 103: 164-169, 2017.

Bakhshandeh E., Rahimian H., Pirdashti H., Nematzadeh G.A.: Evaluation of phosphate-solubilizing bacteria on the growth and grain yield of rice (Oryza sativa L.) cropped in northern Iran. - J. Appl. Microbiol. 119: 1371-1382, 2015.

Bakhshandeh E., Rahimian H., Pirdashti H., Nematzadeh G.A.: Phosphate solubilization potential and modeling of stress tolerance of rhizobacteria from rice paddy soil in northern Iran. - World J. Microb. Biot. 30: 2437-2447, 2014.

Bergottini V.M., Otegui M.B., Sosa A. et al.: Bio-inoculation of yerba mate seedlings (Ilex paraguariensis St. Hill.) with native plant growth-promoting rhizobacteria: a sustainable alternative to improve crop yield. - Biol. Fert. Soils 51: 749-755, 2015.

Bever J.D., Platt T.G., Morton E.R.: Microbial population and community dynamics on pant roots and their feedbacks on plant communities. - Annu. Rev. Microbiol. 66: 265-283, 2012.

Bilger W., Björkman O.: Role of the xanthophyll cycle in photoprotection elucidated by measurements of light-induced absorbance changes, fluorescence and photosynthesis in leaves of Hedera canariensis. - Photosynth. Res. 25: 173-185, 1990.

Carmeis Filho A.C.A., Crusciol C.A.C., Nascente A.S. et al.: Influence of potassium levels on root growth and nutrient uptake of upland rice cultivars. - Rev. Caatinga. 30: 32-44, 2017.

Chandra K., Ingle S.R., Bihari K.: Biofertilizers and its impact on different crops. - In: National Seminar on Biotechnology: Microbes to Man. Pp. 18-19. School of Life Science, Utkal University, Bhubaneswar 2002.

Chapman H.D., Pratt P.E.: Methods of Analysis for Soils, Plants, and Waters. Pp. 309. University of California, Berkeley 1961

Chattopadhyay K., Kuanar S.R., Ray A. et al.: Physiological basis of stagnant flooding tolerance in rice. - Rice Sci. 24: 73-84, 2017.

Chojak-Kozniewska J., Kuznika E., Linkiewicz A. et al.: Primary carbon metabolism-related changes in cucumber exposed to single and sequential treatments with salt stress and bacterial infection. - Plant Physiol. Biochem. 123: 160-169, 2018.

de Souza R., Ambrosini A., Passaglia L.M.P.: Plant growth-promoting bacteria as inoculants in agricultural soils. - Genet. Mol. Biol. 38: 401-419, 2015.

de Vries M.P.C.: How reliable are results of pot experiments? Commun. Soil Sci. Plant Anal. 11: 895-902, 1980.

Fageria N.K., Gheyi H.R., Carvalho C.S.: Yield, potassium uptake, and use efficiency in upland rice genotypes. - In: Proceedings of the II INOVAGRI International Meeting, Fortaleza, Brazil. Pp. 4515-4520. INOVAGRI, Fortaleza 2014.

FAO: Rice Market Monitor 19: 1-38, 2016. Available at: http:// www.fao.org/economic/RMM.
Flexas J., Medrano H.: Drought-inhibition of photosynthesis in $\mathrm{C}_{3}$ plants: stomatal and non-stomatal limitations revisited. Ann. Bot. 89: 183-189, 2002.

Genty B., Briantais J.M., Baker N.R.: The relationship between the quantum yield of photosynthetic electron transport and quenching of ChlF. - Biochim. Biophys. Acta 99: 87-92, 1989.

Jia Y., Yang X., Islam E., Feng Y.: Effects of potassium deficiency on chloroplast ultrastructure and chlorophyll fluorescence in inefficient and efficient genotypes of rice. - J. Plant Nutr. 31: 2105-2118, 2008.

Jiang Q., Roche D., Monaco T.A., Hole D.: Stomatal conductance is a key parameter to assess limitations to photosynthesis and growth potential in barley genotypes. - Plant Biol. 8: 515-521, 2006.

Jin S.H., Huang J.Q., Li X.Q. et al.: Effects of potassium supply on limitations of photosynthesis by mesophyll diffusion conductance in Carya cathayensis. - Tree Physiol. 31: 1142-1151, 2011.

Kalaji H.M., Guo P.: Chlorophyll fluorescence: a useful tool in barley plant breeding programs. - In: Sánchez A., Gutiérrez S.J. (ed.): Photochemistry Research Progress. Pp. 439-463. Nova Science Publishers, New York 2008.

Kramer D.M., Johnson G., Kiirats O., Edwards G.E.: New fluorescence parameters for the determination of QA redox state and excitation energy fluxes. - Photosynth. Res. 79: 209-218, 2004.

Krishna K.R.: Agroecosystems: Soils, Climate, Crops, Nutrient Dynamics and Productivity. Pp. 552. Apple Academic Press, Toronto-New Jersey 2014.

Kuanar S.R., Ray A., Sethi S.K. et al.: Physiological basis of stagnant flooding tolerance in rice. - Rice Sci. 24: 73-84, 2017.

Kumagai E., Araki A., Kubota F.: Correlation of chlorophyll meter readings with gas exchange and chlorophyll fluorescence in flag leaves of rice (Oryza sativa L.) plants. - Plant Prod. Sci. 12: 50-53, 2009.

Li Y.L., Jin Z.X., Guan M. et al.: Effects of soil microbes on photosynthetic characteristics and chlorophyll fluorescence parameters of Elsholtzia splendens under copper stress condition. - Bull. Bot. Res. 33: 684-689, 2013.

Maina J.N., Wang Q.: Seasonal response of chlorophyll $a / b$ ratio to stress in a typical desert species: Haloxylon ammodendron.Arid Land Res. Manag. 29: 321-334, 2015.

Marschner H.: Mineral Nutrition of Higher Plants. Pp. 889. Academic Press, London 1995.

Maxwell K., Johnson G.N.: Chlorophyll fluorescence - a practical guide. - J. Exp. Bot. 51: 659-668, 2000.

Meena V.S., Meena S.K., Verma J.P. et al.: Plant beneficial rhizospheric microorganism (PBRM) strategies to improve nutrients use efficiency: A review. - Ecol. Eng. 107: 8-32, 2017.

Nath D., Maurya B.R., Meena V.S.: Documentation of five potassium- and phosphorus-solubilizing bacteria for their $\mathrm{K}$ and P-solubilization ability from various minerals. - Biocatal. Agric. Biotechnol. 10: 174-181, 2017.

Ntanos D.A., Koutroubas S.D.: Dry matter and N accumulation and translocation for Indica and Japonica rice under Mediterranean conditions. - Field Crop. Res. 74: 93-101, 2002.

Olsen S.R., Cole C.V., Watanabe F.S., Dean L.A.: Estimation of available phosphorous in soils by extraction with sodium bicarbonate. - Soil Sci. Soc. Am. J. 21: 144-149, 1954.

Panhwar Q.A., Radziah O., Rahman Z.A. et al.: Contribution of phosphate-solubilizing bacteria in phosphorus bioavailability and growth enhancement of aerobic rice. - Span. J. Agric. Res. 9: 810-820, 2011. 
Peng H., Weng H.X.Y., Xu H.X. et al.: Effects of potassium deficiency on photosynthesis and photo-protection mechanisms in rice plants. - Chin J Rice Sci. 6: 621-625, 2006. [In Chinese]

Pii Y., Borruso L., Brusetti L. et al.: The interaction between iron nutrition, plant species and soil type shapes the rhizosphere microbiome. - Plant Physiol. Bioch. 99: 39-48, 2016.

Pii Y., Mimmo T., Tomasi N. et al.: Microbial interactions in the rhizosphere: beneficial influences of plant growth promoting rhizobacteria on nutrient acquisition process. A review. - Biol. Fert. Soils 51: 403-415, 2015.

Porra R.J.: The chequered history of the development and use of simultaneous equations for the accurate determination of chlorophylls $a$ and $b$. - Photosynth. Res. 73: 149-156, 2002.

Priyanka, Agrawal T., Kotasthane A.S. et al.: Crop specific plant growth promoting effects of ACCd enzyme and siderophore producing and cynogenic fluorescent Pseudomonas. -3 Biotech 7: 27, 2017.

Salvatori E., Fusaro L., Gottardini E. et al.: Plant stress analysis: Application of prompt, delayed chlorophyll fluorescence and $820 \mathrm{~nm}$ modulated reflectance. Insights from independent experiments. - Plant Physiol. Bioch. 85: 105-113, 2014.

Salvatori E., Fusaro L., Manes F.: Effects of the antiozonant ethylenediurea (EDU) on Fraxinus ornus L.: the role of drought. - Forests 8: 320, 2017.

Sayyad-Amin P., Jahansooz M.R., Borzouei A. et al.: Changes in photosynthetic pigments and chlorophyll-a fluorescence attributes of sweet-forage and grain sorghum cultivars under salt stress. - J. Biol. Phys. 42: 601-620, 2016.

Scagliola M., Pii Y., Mimmo T. et al.: Characterization of plant growth promoting traits of bacterial isolates from the rhizosphere of barley (Hordeum vulgare L.) and tomato (Solanum lycopersicon L.) grown under Fe sufficiency and deficiency. - Plant Physiol. Bioch. 107: 187-196, 2016.

Shah S.H., Houborg R., McCabe M.F.: Response of chlorophyll, carotenoid and SPAD-502 measurement to salinity and nutrient stress in wheat (Triticum aestivum L.). - Agronomy 7: 61, 2017.

Tabassum B., Khan A., Tariq M. et al.: Bottlenecks in commercialisation and future prospects of PGPR. - Appl. Soil Ecol. 121: 102-117, 2017.

Torres Netto A., Campostrini E., de Olivera, J.G. Yamanishi O.K.: Portable chlorophyll meter for the quantification of photosynthetic pigments, nitrogen and the possible use for assessment of the photochemical process in Carica papaya L. Braz. J. Plant Physiol. 14: 203-210, 2002.

Unger I.M., Kennedy A.C. Muzika R.M.: Flooding effects on soil microbial communities. - Appl. Soil Ecol. 42: 1-8, 2009.

Wakiyama Y.: The relationship between SPAD values and leaf blade chlorophyll content throughout the rice development cycle. - JARQ-Jpn. Agr. Res. Q. 50: 329-334, 2016.

Walkley A., Black I.A.: An examination of the Degtjareff method for determining soil organic matter, and a proposed modification of the chromic acid titration method. - Soil Sci. 37: 29-38, 1934.

Wang X., Wang L., Shangguan Z.: Leaf gas exchange and fluorescence of two winter wheat varieties in response to drought stress and nitrogen supply. - PLoS ONE 11: e0165733, 2016.

Weng X.Y., Zheng C.J., Xu H.X., Sun J.Y.: Characteristics of photosynthesis and functions of the water-water cycle in rice (Oryza sativa) leaves in response to potassium deficiency. Physiol. Plantarum 131: 614-621, 2007.

Xue X., Lu J., Ren T. et al.: Positional difference in potassium concentration as diagnostic index relating to plant $\mathrm{K}$ status and yield level in rice (Oryza sativa L.). - Soil Sci. Plant Nutr. 62: 31-38, 2016.

Yaghoubi Khanghahi M., Pirdashti H., Rahimian H. et al.: Nutrient use efficiency and nutrient uptake promoting of rice by potassium solubilizing bacteria (KSB). - Cereal Res. Commun. 46: 739-750, $2018 \mathrm{a}$.

Yaghoubi Khanghahi M., Pirdashti H., Rahimian H. et al.: Potassium solubilising bacteria (KSB) isolated from rice paddy soil: from isolation, identification to $\mathrm{K}$ use efficiency. Symbiosis 76: 13-23, $2018 b$.

Yaghoubi Khanghahi M., Ricciuti P., Allegretta I. et al:: Solubilization of insoluble zinc compounds by zinc solubilizing bacteria (ZSB) and optimization of their growth conditions. Environ. Sci. Pollut. R. 25: 25862-25868, 2018c.

Yaghoubian Y., Siadat S.A., Moradi Taelavat M.R., Pirdashti H.: Quantify the response of purslane plant growth, photosynthesis pigments and photosystem II photochemistry to cadmium concentration gradients in the soil. - Russ. J. Plant Physl+ 63: 77-84, 2016.

Yong J.W.H., Ng Y.F., Tan S.N. et al.: Effect of fertilizer application on photosynthesis and oil yield of jatropha curcas L. - Photosynthetica 48: 208-218, 2010.

Zhang L., Shangguan Z., Mao M., Yu G.: [Effects of long-term application of nitrogen fertilizer on leaf chlorophyll fluorescence of upland winter wheat.] - Chin. J. Appl. Ecol. 14: 695-698, 2003. [In Chinese]

Zhao X.H., Du Q., Zhao Y. et al.: Effects of different potassium stress on leaf photosynthesis and chlorophyll fluorescence in maize (Zea mays L.) at seedling stage. - Agric. Sci. 7: 44-53, 2016.

Živčák M., Olšovská K., Slamka P. et al: Application of chlorophyll fluorescence performance indices to assess the wheat photosynthetic functions influenced by nitrogen deficiency. Plant Soil Environ. 60: 210-215, 2008.

(C) The authors. This is an open access article distributed under the terms of the Creative Commons BY-NC-ND Licence. 